\title{
Analysis of Vessel-Based Marine Accidents and the Economic Risks to Nigeria
}

\author{
Nwokedi Theophilus Chinonyerem ${ }^{1}$, Ibe Calistus ${ }^{2}$, Okeudo Geraldine ${ }^{2}$, Moses Ntor-Ue ${ }^{3}$ \\ ${ }^{1}$ Department of Maritime Management Technology, Federal University of Technology, Owerri, Nigeria \\ ${ }^{2}$ Department of Transport Management Technology, Federal University of Technology, Owerri, Nigeria \\ ${ }^{3}$ Department of Civil Engineering, Rivers State Polytechnic, Bori, Nigeria
}

\section{Email address:}

nwokeditc@gmail.com (N. T. Chinonyerem), callistusibe@yahoo.com (I. Calistus), okeudogeraldine@yahoo.com (O. Geraldine), ntoreeba@gmail.com (M. Ntor-Ue)

\section{To cite this article:}

Nwokedi Theophilus Chinonyerem, Ibe Calistus, Okeudo Geraldine, Moses Ntor-Ue. Analysis of Vessel-Based Marine Accidents and the Economic Risks to Nigeria. Journal of Water Resources and Ocean Science. Vol. 6, No. 6, 2017, pp. 72-84. doi: $10.11648 /$ j.wros.20170606.11

Received: April 13, 2017; Accepted: April 25, 2017; Published: November 28, 2017

\begin{abstract}
The aim of the study is to evaluate the economic loss of vessel-based marine accidents to Nigeria and the impact on marine transport sub-sector output and/or performance. Time series data of 30 years were gathered from the Central Bank of Nigeria $(\mathrm{CBN})$ statistical bulletin, the Nigeria insurance digest, the Organization of Petroleum Exporting Countries (OPEC) annual statistical report. The contribution of marine transport to the Gross Domestic Product (Y), shipping accident economic loss $\left(\mathrm{X}_{1}\right)$, economic losses of offshore oil and gas $(\mathrm{O} \& \mathrm{G})$ drilling accidents $\left(\mathrm{X}_{2}\right)$, and marine oil spill accidents economic losses $\left(\mathrm{X}_{3}\right)$ were obtained and used as the explanatory(independent) variables. The data was analyzed using multiple regression method with $\mathrm{Y}$ as the dependent variable. The hypotheses were tested using t-test. The findings of the study indicates that shipping accidents economic losses and economic losses of offshore oil and gas drilling accidents shows significant impact on the output of the marine transport sub-sector over the period covered by the study. The model expressing the quantitative relationship between $\mathrm{GDP}_{\text {marine transport }}(\mathrm{Y})$, shipping accidents economic loss $\left(\mathrm{X}_{1}\right)$, economic loss of offshore oil and gas drilling accidents $\left(\mathrm{X}_{2}\right)$ and marine oil spill accidents loss $\left(\mathrm{X}_{3}\right)$ is: $\mathrm{Y}=332156363.1+0.167 \mathrm{X}_{1}+0.837 \mathrm{X}_{2}+0.203 \mathrm{X}_{3}+\mathrm{e}$. it was recommended that investment in safety policies and standards be improved with greater focus in reducing accidents induced economic losses in shipping and offshore O\&G drilling maritime operations.
\end{abstract}

Keywords: Vessel-Based, Marine, Accidents, Economic - Risks

\section{Introduction}

The concept of marine accident is the occurrence of an event in a ship or involving any equipment, investment and properties exposed to the marine environment, that resulting to injuries to persons at sea or in port, and damage to the marine property or investment [1]. It encompasses accident in the sea or at port, quayside or anchorage, dockyards or shipyards etc. Marine accidents are caused by exposure to risks, perils and hazards of the marine environment, provided that the accidental objects are at sea or being harnessed for sea movement, in port or in a dockyards and can be protected by a policy of marine insurance. It is immaterial whether the vessel or object involved in accident is sailing or stationary at the point and time of accident [2]. Nigeria being a maritime nation is one of the One Hundred and Sixty Nine (169), and three (3) associate member countries of the International Maritime Organization (IMO) which is an agency of the united Nations [UN], with the mission of regulating safety operations and instrumentation in the global maritime industry [3]. With inland water ways of about ten thousand kilometers $(10,000 \mathrm{~km})$ and extensive coast line of about eight hundred and fifty-two kilometers $(852 \mathrm{~km})$ and territorial sea based on the United Nations Convention on the law of the sea 1982, extending twelve nautical miles or twenty-two kilometers into the open seas, from the shorelines 
of the country, falling fully within the country's exclusive economic zone [3], [4].

Reference [5] reports that seaborne container traffic (container throughput) to Nigerian ports in 2013 stood at two million, Seven hundred and twenty thousand, four hundred and twenty two TEUS (2,720, 422 TEU'S), representing an average of nine hundred and nine thousand four hundred and seventy four TEU'S (909,474 TEU'S) per annum between the 2011 to 2013 period. National statistics indicates that the total value of export shipping trade (Export trade by sea) and imports shipping trade (sea borne import trade) in the year 2013 were fourteen trillion, seven hundred and thirty five billion, nine hundred and seventy seven million, seven hundred and sixty thousand naira $(14,735,977,760,000.00)$ and nine trillion, eighty four billion, four hundred and fifty four million, seven hundred and thirty thousand naira $(9,084,454,730,000.00)$ respectively, while the cargo throughput of the Nigerian ports excluding crude oil terminals in the same year was $76,886,997$ million metric tons [6-8]. Further reports from the Nigerian ports authority (NPA) reveals that in the year 2013, 5232 ships transited to the ports of Nigeria while an average of 2,200 offshore service boats serviced the logistics needs of the oil and gas (O\&G) industry in the coastal trade [6]. Within the Nigeria coastal regions and internal waters, runs extensive oil pipeline networks of over $7000 \mathrm{~km}$ extending to the shores and numerous oil exploration and exploitation platforms.

The above statistics represent the economic strengths of the economy of the Nigeria's marine transport industry/subsector and points towards the potentials of the sub-sector to contribute meaningfully to the Gross Domestic Product, economic growth and development. Statistics from the Central Bank of Nigeria (2013) reveals that the average contribution of maritime transport sub-sector (GDP marine transport) to the Gross Domestic Product of the Nigeria economy in 2013 alone was six billion, two hundred and twenty million, four hundred and seventy thousand naira (\#6,220,470,000.00). The economic contribution of the marine economy of Nigeria can be maximized given the capacities of the contributing variables as earlier statistics reveal. it is viewed that the contribution of this sub-sector of the economy has continually remained limited and below expected benchmarks and targets each year following high trend of marine perils and hazards (causal factors of accident) to which the investments are exposed, this equally has economic and financial costs and implications which consequently hinder the maximization of the contribution of the maritime transport sub-sector to the national output (GDP) of Nigeria [9].

Reference [10] explains hazards and perils of the sea as unforeseen occurrences making vessels, underwater installation, seaborne cargo, oil and gas drilling rigs and platforms, and on board-personnel vulnerable to risks of marine accident with the attendant economic loss. Reference [11] asserts that the prevalence of hazards and perils of the sea, exposes maritime prosperities and investment in ships to risk of accident and loss of various nature, this necessitates the application of formal safety assessment (FSA) and other forms of risk assessment methods as well as proper implementation of other International maritime Organization (IMO) convention instruments to limit the occurrence of maritime accidents and consequent economic losses occasioned by it.

Reference [2] further defines a marine accident as one or more unexpected and undesired marine incident, which result in death or personal injury to crew, damage or loss of marine properties and seaborne cargo and harmful to the marine environment. Safety has always been considered as a critical feature in almost all marine operations, safety must have equal consideration with environmental and economic impact [12]. Since marine accident is likely to have serious commercial and financial consequences. It is therefore important to keep all risks in good control through proactive safety management. This requires the measurement of the economic cost of ship-based accidents to properly manage it. The Nigeria Maritime Administration and Safety Agency (NIMASA) Act made provisions for institution of an accident investigation committee, to cause an inquiry into the reported accident cases in the maritime domain of Nigeria and Nigeria flagged vessels. The Act however did not note the importance of extending investigations to finding the impact of marine accidents on the economy as it seems to center more on investigating to limit environmental impact of pollution, accident frequency, fatality (death) rates and injury to onboard personnel and passengers. The implementation of the section of the NIMASA Act dealing with investigation of accident by an appointed committee is equally believed to have been politicized over the years due to appointment of politicians into the committee rather than professionals. As a result while many coastal nations in boast of serious strives and certainty achieved in limiting marine accidents and the economic impacts, through diligent implementation of safety and loss control measures, as evidenced in the data bases they maintain for marine accident. The same cannot be said of marine accident investigation, measurement and control in Nigeria, as it remains a game of probability even as there appear to be no reliable public sector ship-based accident database for Nigeria.

In the opinion of reference [13], "You can't manage or control it, if you can't measure it". To measure and/or estimate the impact of vessel-based marine accidents losses on the economy with precision, marine accident investigation is an important first step. It becomes an equally impossible task to ascertain the extent of losses caused by marine accidents when there is no professional marine accident investigation board, or where the marine safety authority lacks a developed effective and professional accident investigation department.

In the views of reference [14], accidents impose various categories of economic costs which include: property damage cost (damage accident), injury and death cost (injury and death accident), cost imposed on economy as a result of 
accident induced pollution (spill/ pollution accident), cost of police services, court and insurance services, cost of safety measures implementation among others. The opinion of [14] receives support from the opinions of references [15], [16], whose studies centered on valuation of damage accidents in the marine industry. Reference [16] identifies the economic losses of marine damage accidents to include: shipping accident losses, offshore oil and gas (O\&G) drilling accidents losses, and marine oil spill accidents losses. This study will center on the economic losses of the various kinds of vesselbased marine damage accidents and the effects on the output of the marine transport sub-sector of Nigeria from 1984 to 2013 covering a 30 years period. The contributions of maritime transport to economic growth and development of Nigeria will neither be sustained nor maximized, until the economic losses of marine accidents in Nigeria is measured with precision and controlled by use of effective safety management instruments.

\subsection{Objectives}

The main objective of the study is to ascertain the impact of marine accident economic loss on the output of Nigerian marine transport sub-sector of the economy from 1984 to 2013. Other specific objective are:

(i) To assess the impact of shipping accidents economic loss on the Nigerian marine transport gross domestic product $\left(\mathrm{GDP}_{\text {marine transport }}\right)$.

(ii) To examine the effect of the economic loss of offshore oil and gas $(\mathrm{O} \& \mathrm{G})$ drilling accidents on the output of the marine transport subsector of Nigeria.

(iii) To evaluate the impact of marine oil spill accidents on the GDP marine transport

(iv) To compare shipping accidents economic loss and insurance expenditure on shipping accidents loss control and management.

\subsection{Hypotheses}

$\mathrm{H}_{\mathrm{Oa}}$ : There is no significant impact of shipping accidents economic losses on $\mathrm{GDP}_{\text {marine transport }}$ over the period covered in the study.

$\mathrm{H}_{\mathrm{ob}}$ : Economic losses of offshore O\&G accidents has no significant impact on GDP

$\mathrm{H}_{\mathrm{oc}}$ : marine oil spill accidents losses does not show significant impact on the GDP $\mathrm{Garie}_{\text {transport }}$

$\mathrm{H}_{\mathrm{od}}$ : There is no significant difference between shipping accidents economic loss and insurance expenditure for the control and management of shipping accidents losses.

\section{Brief of Related Literature}

\subsection{Conceptual Framework}

Reference [17] explains an accident as unexpected, unplanned and unintentional series of events leading to the physical injury of a person at work and/or damage to properties, equipments and the environment. In a study on theories of occupational accident, reference [17] opines that accidents occur when workers, properties and equipment are exposed to a danger factor (hazard), such that the worker is injured and the property is damaged with diminished value. Presenting a study guide on accident investigation and control, reference [18] defines the concept of accident as the final event in an unplanned process that results in injury, illness, property damage and possible environmental damage. It is the final effect of multiple causes and an event, that result in a damage of state of persons and properties involved [18]. From the foregoing, it is observable that the occurence of accident diminishes the economic value and structure of properties and health states of persons involved. Reference [18] distinguishes between accident and incidents, while accidents are observed to cause injuries and damages, incidents do not cause injuries and damages. Accidents also result from many factors, simultaneously interconnected, cross-linked events that have interacted in some dynamic way. It identifies that accidents also result from hazardous conditions and unsafe behaviours which represent risks that have been ignored and tolerated within the safety management system. In the guide for hazard analysis and control in a work environment, it notes that hazards are dangers, unsafe workplace conditions and practices which threaten physical harms to employees and to property and environment. It posits that these hazards (dangers) represent risks of damages and injuries that could occur with accidents, once there is exposure to it [18].

In the views of reference [19], an accident is an occurrence that involves a sequence of events that must encompass unintentional injury or damage. Reference [19] posits that accident phenomenon is distinguished from other phenomena such as murder, sabotage, suicide, war, and other willful injurious event by the singular characteristics of unplanned, unexpected or unintentional injury and/or damage. Figure 1 below is a key illustration of the accident phenomenon as illustrated by reference [19] in observing the event in the beginning and end of accident.

\section{ACTIVITY EVENTS AND OUTCOME FOR ONE ACTOR}

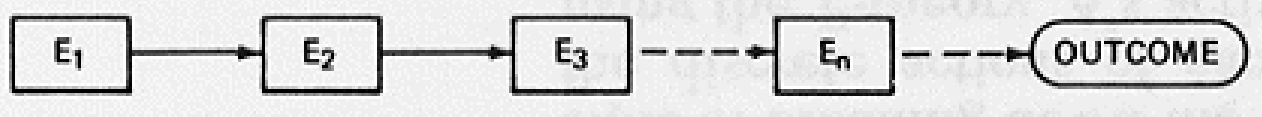

Source: Reference [19].

Figure 1. Accident is assumed that involve the occurrence of a set of successive events that produce unintentional harm. 


\section{ACTIVITY EVENTS AND OUTCOME FOR TWO ACTORS}

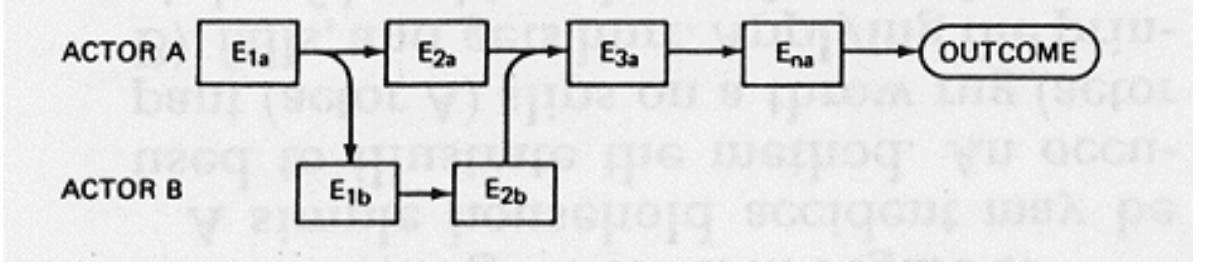

Source: reference [19].

Figure 2. Accident causing events and activities in terms of their chronological relationship.

Reference [17] supporting the earlier position of [18] notes that the risk of traffic accident is influenced by the level of exposure to occupational/traffic related hazards. This agrees with the position of reference [18], that exposure to risks (hazards) causes accident. Risk is the probability than an accident (event) will occur and adversely affect the achievement of objectives [19]. Reference [20] in reference [21], considers risk as the chance of injury, damage or loss. Risk is further explained as an event where something that is of value to humans (including humans themselves) is at stake and where the outcome is uncertain [21-22].References [2324] definie risk as the effects of uncertainty on objectives notes that risk is the possibility that an event will occur and adversely affect the achievement of objectives.

A diligent observation of the above definitions of risk show a synonymous relationship between accident and risk with the definition of both having common elements of unexpected loss, injury, damage, adverse outcome, uncertainty, probability, severity of consequences, etc. The concept of accident and risk therefore denotes the likelihood that employees, properties and investment exposed to hazards and unsafe condition may experience an event/action, whose casual factor may be multiple, single or in-chain, that will change its state by resulting to injury, damage and/or loss.

The advent of motorized transport, offshore technology, and advancement in industrial technology has led to development of sea going vessels of various kinds, oil and gas exploration rigs, floating production storage and offloading systems (FPSO's) and water crafts of various kinds. Advancement in offshore technology and ocean engineering also offers opportunity for development of underwater exploration and exploitation vehicles, pipeline technology system, cargo handling equipments of various kinds and capacity, onshore/port technology systems, all produced through the mastering and use of marine/ocean engineering and offshore technology and put into the sea for purposes of surface sea transportation, (shipping), underwater exploitation, surveillance and hydrographic studies, or stationed permanently at sea or near to enhance the purposes of harnessing the marine resources to the socio-economic benefit of the state. The concept of marine/maritime accident is the occurrence of an event/risks, in a ship or involving equipment, investment and properties exposed to the marine environment, that resulting to injuries to person at sea or in port, and damage to the marine property or investment [1]. It encompasses accident in the sea or at port, quayside or anchorage, dockyards or shipyards etc. Maritime accidents are caused by exposure to risks, perils and hazards of the marine environment, provided that the accidental objects are at sea or being harnessed for sea movement, in port or in a dockyards and can be protected by a policy of marine insurance. It is immaterial whether the vessel or object involved in accident is sailing or stationary at the point and time of accident [2]. The marine accident casualty investigation boards further defines a marine accident as one or more unexpected and undesired marine incident, which result in death or personal injury to crew, damage or loss of marine properties and seaborne cargo and harmful to the marine environment [2]. The study adopted the definition given by reference [2] as our definition of marine accident.

The concept of maritime accident according the marine accident and casualty investigation boards is one or more unexpected and undesired marine incident, which result in death or personal injury to crew, damage or loss of marine properties or seaborne cargo, and harmful to the marine environment. Marine incident on the other hand was defined as undesired abnormal events occurring in the course of a marine adventure and likely to cause danger to man, ship's architecture work or environment [2]. References [2] and [25] opines that marine accident may not be limited to accident involving sea-going vessels and inland water boats but includes onshore mishaps such as crane cargo/handling accident in ports, accident involving oil exploitation platforms and mobile drilling units, accident in dockyards, collision leading to actual or pressurized loss of ship, her abandonment, material damage to her or disablement. While vessel accident is an unintended happening, its severity may vary from no vessel damage to loss of entire cargo, and crew injury to death [26]. However, the code for marine accident and casualty investigations distinguishes between "very serious" and "serious" casualties. Very serious means a casualty to a ship which involves the total loss of ship and its cargo, loss of life or severe environmental pollution or damage. Serious casualty means a casualty which does not quality as a very serious casualty and which involves fire explosion, grounding, contact, heavy weather damage, ice damage, hull cracking or suspected hull defect resulting in structural damage rendering the ship unseaworthy such as 
penetration of the hull underwater, immobilization of main engines, extensive accommodation damage, pollution and /or breakdown necessitating towage or shore assistance [2], [27], [16]. Reference [28] opines that the main legal basis that formed the international background for maritime accident investigation lies in the United Nation convention on the law of the sea (UNCLOS), which states in article 9A that it is the responsibility of the flag state to institute an inquiry (investigation) into accidents on the high sea. Accidents occurring elsewhere, such as in coastal and inland waters are not covered by the UNCLOS, though the right of the coastal state to extend investigation to accident on such waters is not in contention and has been viewed as important in determining economic cost of marine accidents and their control measures [28].

Reference [29] in a study on analysis of maritime transportation risk factors grouped maritime accident into the following groupings:
a. Foundering
b. Missing
c. Fire explosion
d. Grounding
e. Collision / contact
f. War loss / hostilities
g. Mechanical fault / problem
h. Hull problem
i. Navigational problem
j. Other problems not specified above.

The study further observed that accident in the marine industry are further identified by the data-bases of maritime casualty maintained and published by organizations that conduct accident investigation and analysis and regular statistical data updates, such organization include Lloyds maritime information services (LMIS), UK department of transport maritime accident investigation branch (MAIB), Institute of London underwriters (ILU), classification societies such as Det Norske Veritas (DNV), American Bureau of shipping (ABS), United States Coast Guard (USCG), The International Association of classification societies (IACS), and the Maritime Accident Investigation Board (MAIB) of various maritime states [29].

\subsection{Theoretical Framework}

Theoretically, the economic loss and impact of marine accident on the economy can be estimated based on the theories of accident causation, accident investigation and accident/risk management and loss control. These include the domino theory, the theory and principles of marine insurance, human capital theory (Gross Output Model) and the economic theory of natural resource damage assessment based on total revenue, price and quantity, (output) relationship, among others [11], [30], [14] and [16].

\subsubsection{Accident / Loss Causation Theories}

There exist many theories which seek to explain the causal factors of accident and the accident loss. The reason for many of the theories is to lay sound foundation for the understanding of the key accident causal factors, to enable application of control and management measures, to eliminate or reduce accident occurrence [31]. Reference [13] opines that accident theories support the valid opinions that accident are not always Acts of God and misfortunes to be suffered by people not at peace with gods, as believed until the $19^{\text {th }}$ century when accident theory began to explain the causal factors of accidents. Thus accident theories provide explanation for occurrences of accidental losses and lay basic foundational steps for effective accidental damage and loss control and management. Some of the classical accident causation theories reviewed in this work include; the Domino theory, The Human Factor Theory (HFT), the Accident Incident Theory (AIT), Epidemiological Theory, the systems theory, the Accident Proneness Theory (APT), the combination theory of accident causation, Behaviour Theory (BT), the Energy Release Theory (ERT), energy damage model [32]. Each of the accident causation theories attempts to predict accident and thus prevent its occurrence.

\subsubsection{The Domino Theory}

Reference [33] observes that the domino theory was developed and advanced by Heinrick in1959. In developing the domino theory, Heinrick conducted a research on industrial accident and concluded that $88 \%$ of accidents are caused by unsafe acts committed by people, $10 \%$ by unsafe condition and $2 \%$ by acts of God. The $2 \%$ caused by acts of God, he termed unavoidable accident. Thus the domino theory views that $98 \%$ of accident can be avoided by avoiding the causal factors [34].The domino theory explained that injury / loss results from series of events one of which is the accident itself. An accident it explains only result from an unsafe acts committed by someone and / or a physical hazard. Essentially, removal of the unsafe act or the unsafe condition prevents loss and damage. The theory states that while most accident result from peoples unsafe behavior and unsafe conditions, unsafe behaviours and conditions do not always immediately result in accident [35]. Therefore finding the reason why people commit unsafe behavior can guide in adopting corrective measures. According to domino theory, the severity of an accident loss or damage is by chance rather than design and the accident that cause the loss and / or damage is preventable. The opinion of the domino theory is that management ought to take responsibilities for safety with the supervisor being the key person in the prevention of occupational and industrial accidents seeing as there were indirect losses incurred besides direct ones [34]. Explaining the Domino theory, references [34] and [35] proposed a sequence consisting five factors that followed sequentially, that is, one factor resulting in the next. The first was ancestry and social environment which explains that negative traits causing people to commit unsafe actions may be inherited or acquired from the environment one was socialized. The second factor is fault of a person which explains that people act in unsafe manner as a result of the negative traits they acquired. The third factor is unsafe act or physical hazard / unsafe condition which directly result to accident. The fourth 
factor is accident which results in injury, damage and / or loss. The fifth and last factor is injury, damage and / or loss which is the consequence of accident. The figure below is an illustration of accident and loss occurrence by the domino theory.

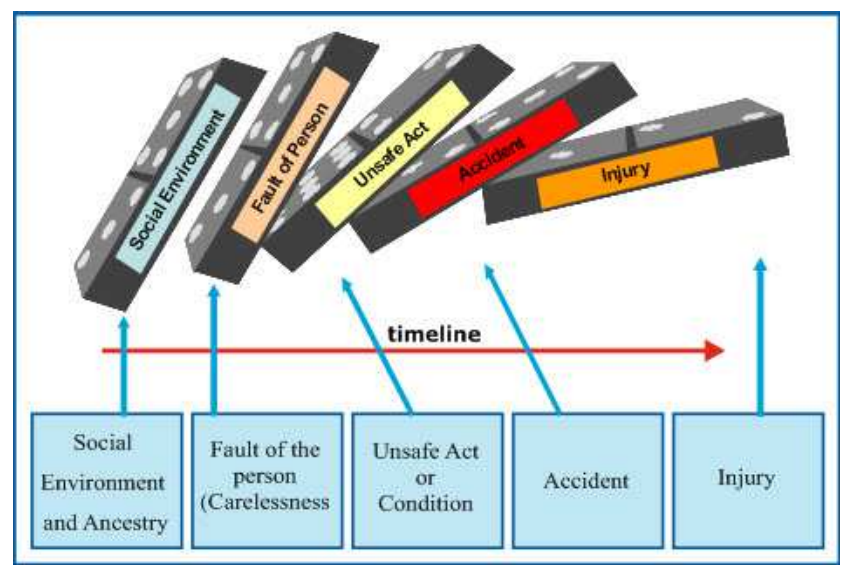

Figure 3. Heinrich's Domino Model of Accident Causation.

Source: Adopted from Disaster Management Institute, Bhopal, Online Explanation of Domino theory.

\subsubsection{Accident Investigation Theories}

Reference [36] defines accident investigation (AI) as the structural process of uncovering the sequence of events that produced or had the potential to produce injury, death, property damage and/or loss, to determine the causal factors (root and surface causes), impacts and corrective action while reference [32] proposes that the idea of accident investigation is to apply analytical techniques to find the cause and consequences of accident. Investigation employs test of engineering experiments to discover the rate of accident root causes and consequences while answering the question of why the accident happened [32] The American Bureau of Shipping [37] asserts that the role of the accident investigation process is to provide proper safeguard to prevent and mitigate accident effects. If adequate safeguards are in place, any losses that occur will be acceptable losses. Reference [37] notes that individual organizations and states may however have other objectives to achieve with accident investigation (AI) which may include:

a. To protect the safety and health if workers particularly the human resources of the maritime industry.

b. To preserve the organization's human capital and labour resources.

c. To fulfill the legal and statutory obligations of the state with regards to implementation of the IMO instruments particularly the United Nations Conventions on Law of the Seas (UNCLOS) which require coastal states to conduct an inquiry and investigation into accidents in their maritime jurisdiction and involving their flag ships.

d. Improve quality reliability, output and productivity of the sub-sector

e. Ensure continual and sustenance of service to clients and customer

f. Comply with national regulatory and insurance requirements

g. Educate management staff and employees

h. Control losses imposed by accident.

i. Demonstrate management concern and employee involvement

j. Advice others of unrecognized risk and or more effective risk management strategies

k. Comply with organizational and industry policy

1. Classify accidents and generate data.

It was reported by reference [37-38] that accident investigation theories (AIT) aims to aid accident investigation (AI) to fulfill investigation roles and therefore cannot serve to merely explain proximate causal factors, as accident cause theories do. Accident investigators employ analytical, structural and scientific processes, dealing with different levels of analysis to ascertain the root causes and consequences of an accident, thus, while the cause theories are good at explaining the accident phenomena, they do not possess the dept of structural analysis needed to guide investigation processes [37].

While the accident causation theories (ACT) may explain the proximate causes of accident and the nearest intermediate cause, there may exist serial (connected more than one) intermediate cause and root causes, also connection often times exist between and/or among the root, intermediate and proximate causal factors which only thorough accident investigation can reveal. These forms the basic reason for specific accident investigation theories (AIT), to structurally, analytically, and scientifically guide accident investigators (AI's) and investigation processes [39], [37]. Reference [33] notes that among the accident investigation theories are; the single event theory, the chain-of-events theory, the branched event chain theory, and the multi-linear sequences (process) theory.

\subsubsection{The Single Event Theory}

The single event accident investigation theory assume that every accident consist of a single event that has a cause. According to the theory, the investigative task is therefore geared towards finding the single cause and correcting it. The theory often relieves the victim of blame and is notorious for blaming it on the factor beyond the victims control such as fate, acts of God or ill luck. Thus it discourages further examination/investigation into the accident phenomenon in an attempt to forestall a reoccurrence of the same [40], [33] [41]. The theory assumes reliability of accident phenomenon, opining that someone or something failed, was at fault or to blame. Otherwise accident is an act of God [41].

\subsection{Accident/Risk Management Principles and Loss Control Theories}

Risk is defined as the effect of uncertainty on objectives [42]. Reference [43] opines that risk is the likelihood or probability that an event (incident) will occur and adversely affect the achievement of an objective function. Risk itself 
has uncertainty [43]. According to [44] risk management is the identification, assessment prioritization and response, followed by coordinated and economical application of resources to minimize, monitor, and control the probability and impact of unfortunate events (accidents/risk) and to maximize the realization of goals, objective function and opportunities. The objective of risk management is to assure that uncertainty does not deflect the endeavor from the business goals [44]. Reference [45] views risk management as the process that attempts to manage the uncertainty that influences the achievement of objectives, with the goals of reaching the objectives and thus creating value for the organization in which it is applied.

It was observed by reference [43] that the theory and principles of risk management processes, methods and control are safety tools and devises which organizations and safety managers must adopt to have good control over risks. However professionals note that risk control and management methods enunciated in the risk management theory have certain key components in common which includes: Internal environment, objective setting, risk identification, risk assessment, risk response, information and monitoring [43-46]. Reference [19], supporting the views of [46] opines that risk management follows six (6) basic process as depicted in figure 4 below.

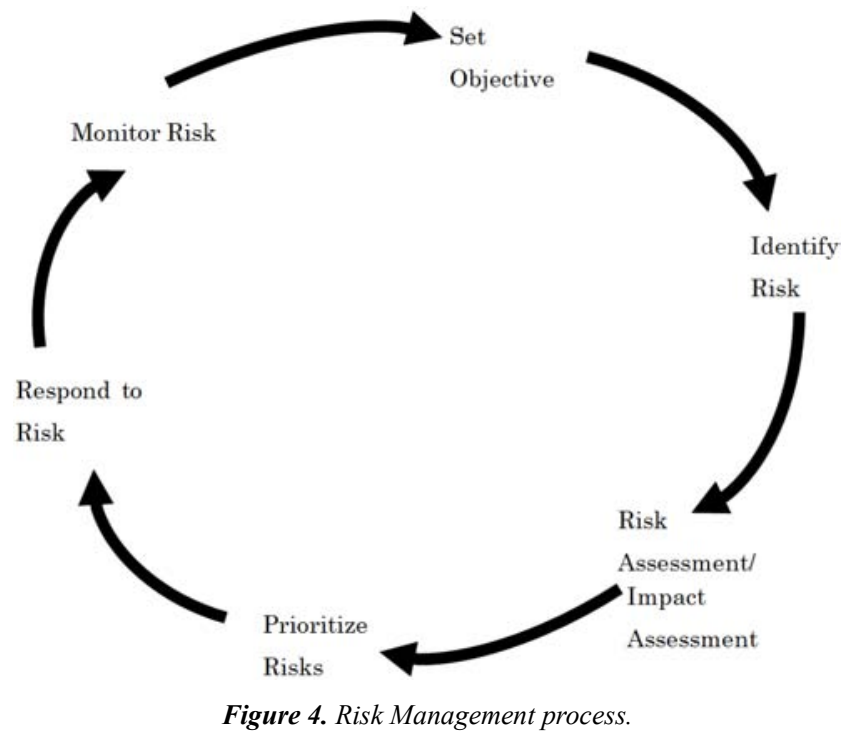

Source: Risk Management process presented as a cycle based on the design by At de Wild (Versilusi, 2014)

The first step is to clearly state the objective (goal) to be achieved which also helps to derive exactly what is exposed to risk. This is followed by risk identification which identifies the events (risks) that form the hazards/threats to the objectives. The result of the risk identification process is a register, (list) containing internal and external risks that form threat to the maritime property, persons or investment. This is followed by the third (3) step which is assessment of the likelihood of occurrence and impact of each identified risk. Risk assessment can be done with either qualitative or quantitative way. It is expected that the impact be expressed in monetary quantities or magnitude of economic loss (damages) and injuries. Both risk identification objective setting and risk assessment are done using tools and methods which were later discuss under formal safety assessment (FSA).

The fourth process of risk prioritization is done by comparing individual risk, frequently used methods here include the expected value method, which ranks risks according to the product of a risk probability and impact (consequence) and plotting risks on a risk matrix which offers a visual aid to compare risks. See figure 4, below in risk matrix.

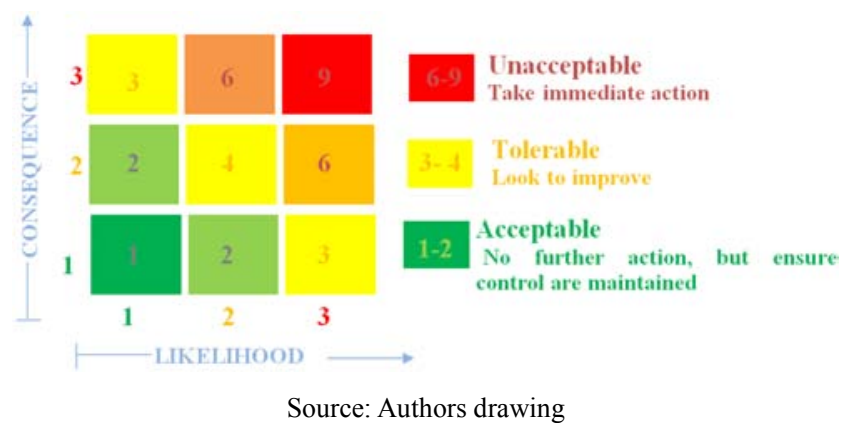

Figure 5. Ranking and comparing of Hazards/risk.

When risks have been prioritized an appropriate risk response or management method is applied to mitigate, manage or deal with risk. This include risk avoidance, risk reduction, risk retention and risk transfer [19], [42], [46]. The last process in the risk management process is monitoring to ensure that the risk does not constitute threat anymore. Reassessment can often or periodically be done depending on residual risk severity. This monitory step is the final step in the risk assessment process and serve as a feedback Mechanisms that closes as well as continuously sustain the risk management process. References [45-46] agree that the risk management theory identifies four strategic principles of risk management for industrial risk management to include risk avoidance/risk prevention, risk reduction, risk retention and risk transfer (insurance). The adoption of either of the above risk management strategies/principle or a combination of strategies by organizations will however depend on the expected utility to be derived from such. Decision theory is required for choice making so that the risk management and control principle that maximizes utility is preferred. References [47-48] upheld the choice of risk management tool based optimal utility criteria as best.

\section{i. Risk Avoidance/Termination or Prevention}

References [45], [49-50] agrees that risk avoidance as a risk management option involves the termination, elimination, prevention and/or shutting off of all activities that causes the risk to exist. Risk avoidance may seem the answer to all accident risks, but avoiding risks because of the likelihood of accident also imposes a new risk of losing out on the potential gain that acceptance of the risk prone activity 
or operation may have offered. Declining to invest in a seaborne trade and maritime business venture to avoid the risk of accident related loss will certainly also avoid the possibility of earning profits [51].

\section{ii. Risk Reduction}

Since it is impossible to avoid an activity involving risk of accident and still gain the potential and opportunities offered by the avoided risk prone activity, and since marine business enterprises themselves are exposed naturally to a pool of marine perils/risk which an entrepreneur must have to contend with (reasonably accept) in other to gain profit and/or achieve objectives. It follows that risk reduction strategies as a principle of risk management offers a better option for industrial risk management than avoidance as it seeks to mitigate risk, while still retaining/offering the opportunity to gain from the potentials offered by such risk prone operation [52]. Reference [53] explains that risk reduction is risk optimization, which involves reducing the severity of the loss or the likelihood of the loss from occurring. For example, sprinklers are designed to put out a fire to reduce the risk of loss by fire onboard. This strategy may impose prohibitive cost and in some cases, the mitigation strategy itself may create room for more loss by imposing /creating a new risk dimension [54-54]. Acknowledging that risk can be positive or negative, optimizing risks of economic losses means finding a balance between negative risk and the benefit of the operation or activity; and between risk reduction effort applied. Thus reduction or optimization of risk of economic losses will achieve levels of residual risks mitigated from non-tolerable regions to tolerable or acceptable regions [56].

This implies that by risk reduction leading to risk tolerance, the organization still bears the impact of the economic losses, damages and injuries imposed by the occurrence of the risk.

\section{iii. Risk Retention}

Reference [57] opines that risk retention involves accepting the loss, or benefit from a risk when it occurs. True self-insurance falls in this category. In the opinion of reference [58-59] risk retention is risk tolerance, which involves leaving the risk as it were without taking any action of working to transfer/insure the risk of loss. This is possibly obtainable where a risk of economic loss is of negligible size and is considered an acceptable risk level either before or after the implementation of other risk responses, and cannot be further responded to. Furthermore, a risk of substantial impact can be tolerated if the presence of the risk is vital for the existence and continuity of an organization. Such risks retained or tolerated must be subjected to monitoring to deter it evolving from tolerably acceptable risk regions to unacceptable risk regions.

Reference [60] observes that risk retention serve as a viable strategy for small risk, where the cost of insuring against the risk would be greater over time than the total losses sustained. Reference [61] further reveal that all risk that are avoided or transferred is retained by default. This includes risks that are so large or catastrophic that they cannot be insured against or the premium would be impossible to be met. Risk retention may also be acceptable option if the chance of a very large loss is small or if the cost to insure for greater coverage amount is so great it would hinder the goals of the organization too much.

\section{iv. Risk Transfer (Insurance)}

Risk transfer is viewed as sharing with another party (third party) the burden of loss or the benefit of gain, from a risk, and the measure to reduce the risk [54], [45]. Reference [19] opines that risk transfer is fully or partially reducing the impact or severity of loss or damage imposed by risk of accident occurrence using risk sharing, made possible by purchase of insurance policy to cover the property from risk of loss. Thus purchase of an insurance contract is often described as risk transfer. However, technically speaking, the buyer of the insurance contract generally retains legal responsibility for losses transferred. This means that insurance may be defined more accurately as post-event compensatory mechanisms. The risk still lies with the policy holder, the insurance policy simply provides that ifan accident (the event) occurs, involving the policy holder, then some compensation (indemnity) may be payable to the policy holder that is commensurate with the loss/damage [62]. In the marine industry, the practice of marine insurance serve as a risk transfer mechanisms for marine risks/accident management and control.

\section{Methodology}

The study adopted an analytical method in which time series data of 30 years period (1984 to 2013) on the economic losses of three categories of damages/losses imposed by accidents in the marine industry were collected from Nigerian Insurers Digest 2003, 2008 and 2014 editions and Central Bank of Nigeria annual financial statistical bulletin, various editions and Nigerian national Petroleum Corporation statistical report. Data on the Gross Domestic Product of marine transport over the period from 1984 to 2013 was also obtained to represent the output of the marine industry and denoted by (Y) as the dependent variable. The multiple regressions analysis statistical model was used to analyze the time series using SPSS software. The GDP marine transport was used as the dependent variable $\mathrm{Y}$ and the economic losses of shipping accidents, offshore oil and gas drilling accidents, and marine oil spill accidents denoted with $\mathrm{X}_{1}, \mathrm{X}_{2}$, and $\mathrm{X}_{3}$ respectively, forming the independent variables. Using the method, the relationship among the four variables is as modeled below:

$$
\mathrm{Y}=\mathrm{a}+\mathrm{b}_{1} \mathrm{X}_{1}+\mathrm{b}_{2} \mathrm{X}_{2}+\mathrm{b}_{3} \mathrm{X}_{3}+\mathrm{e}
$$

Where $\mathrm{Y}=\mathrm{GDP}_{\text {Marine transport }}$

$\mathrm{a}=$ constant term

$\mathrm{X}_{1}=$ Shipping accident economic loss

$\mathrm{X}_{2}=$ Offshore oil and gas drilling accident economic loss

$\mathrm{X}_{3}=$ Economic loss of marine oil spill accident 
$b_{1} \ldots b_{3}=$ coefficients of terms.

$\mathrm{e}=$ error term

\subsection{Discussion of Result and Findings}

The findings from the result indicates that average output of marine transport sub-sector measured by the Gross Domestic Product within the period of the study is $907,203,000.00$ naira, representing the mean contribution of the marine transport sub-sector to the national output relative to the investment made in the subsector within the period. The result indicates mean shipping accidents, offshore O\&G drilling accidents and marine oil spill accident economic losses of 1,633,633,300.00 naira, 916,041,733.00 naira and $138,561,582.80$ naira respectively per annum from 1984 to 2013. This implies that loss control and safety management measures (safety measures) has not achieved acceptable results and/or targets particularly as it relates to shipping accidents and offshore $\mathrm{O} \& \mathrm{G}$ drilling accident. This is because comparisons of their mean losses over the period to mean output of the industry in the same period shows higher mean marine (shipping and offshore O\&G) accidents losses than mean output of the marine industry. See table 1 below:

Table 1. Descriptive Statistics.

\begin{tabular}{lll}
\hline & Mean & Std. Deviation \\
\hline GDP Maritme & 907203000.0000 & 1085000877.60699 \\
Ship Accident Loss & 1633633300.0000 & 2627483675.13462 \\
Oil Spill Loss & 138561582.8037 & 161752904.39467 \\
Offshore O \& Gas accident Loss & 916041733.3333 & 2087199695.60681 \\
Aggregate marine accident loss & 2688236615.08 & 30 \\
\hline
\end{tabular}

Source: Authors computation.

The aggregate mean marine accident economic loss based on the result as shown in the table1 above is 2688236615.08 naira per annum. The implication is that more is lost in the marine transport sub-sector economy to marine damage accidents each year than the annual contribution of the subsector to national output. The ratio of average aggregate marine accidents economic loss to average output of the subsector is $3: 1$, proving further the non acceptability of and failure of present safety management and loss control measures. There is no doubt that risk transfer may have played a key role in the indemnification of these losses, however, other loss control and safety tools could not limit marine accident risk levels to acceptable regions (see risk matrix in figure 4$)$, considering the output $\left(\mathrm{GDP}_{\text {marime }}\right)$ of the subsector. If the present trend continues, it is obvious that economic sustainability of marine operations and seaborne trade cannot be guaranteed.

Table 2. Modeling The Impact Of Marine Accidents Economic Losses On Gdpmarine transport and Test of Model Significance.

\begin{tabular}{lllllllllll}
\hline \multirow{2}{*}{ Model } & \multirow{2}{*}{$\mathbf{R}$} & \multirow{2}{*}{ R Square } & $\begin{array}{l}\text { Adjusted R } \\
\text { Square }\end{array}$ & $\begin{array}{l}\text { Std. Error of the } \\
\text { Estimate }\end{array}$ & \multicolumn{2}{l}{ Change Statistics } \\
\cline { 5 - 9 } & & & R Square Change & F Change & df1 & df2 & Sig. F Change \\
\hline 1 & $.798^{\mathrm{a}}$ & .637 & .609 & 759982372.85481 & .637 & 11.036 & 3 & 26 & .000 & \\
\hline
\end{tabular}

Source: Authors computation.

The table 2 above shows that the multiple $\mathrm{R}$ indicating the degree of association between the output of the marine subsector and marine accidents economic loss is 0.798 . The indication is that approximately 80 percent degree of association exists between the dependent (marine transport output) and independent variables (shipping accidents, O\&G drilling accidents and marine oil spill accidents economic losses). The $\mathrm{R}$ square is 0.637 . The $\mathrm{R}$ square value shows that
63.7 percent variation in the Gross Domestic Product of the marine transport economy over the years covered by the study is explained by the economic losses of maritime accident. Thus the model is highly significant.

The coefficient of terms of marine accidents economic losses formodeling the quantitative relationship and impacts is as shown the table below:

Table 3. Parameter coefficients of marine accidents Losses.

\begin{tabular}{|c|c|c|c|c|c|c|}
\hline \multirow{2}{*}{\multicolumn{2}{|c|}{ Model }} & \multicolumn{2}{|c|}{ Unstandardized Coefficients } & \multirow{2}{*}{$\begin{array}{l}\text { Standardized Coefficients } \\
\text { Beta }\end{array}$} & \multirow{2}{*}{$\mathbf{T}$} & \multirow{2}{*}{ Sig. } \\
\hline & & B & Std. Error & & & \\
\hline \multirow{3}{*}{1} & (Constant) & 332156363.041 & 191967632.244 & & 1.730 & .095 \\
\hline & Oil Spill Loss & .837 & .918 & .125 & .912 & .370 \\
\hline & Offshore Accident & .203 & .082 & .391 & 2.478 & .020 \\
\hline
\end{tabular}

Source: Authors computation based on collected data

From the table3, the model showing the quantitative effects of shipping accidents economic loss, economicloss of offshore O\&G accidents, and marine oil spill accidents loss on the output of the marine transport subsector is: $\mathrm{Y}=$ 
$332156363.1+0.167 \mathrm{X}_{1}+0.837 \mathrm{X}_{2}+0.203 \mathrm{X}_{3}+\mathrm{e}$

Table 4. Comparative Analysis On Shipping Accidents Economic Loss And Insurance Expenditure On Shipping Accidents Loss Control.

\begin{tabular}{llllll}
\hline & & Mean & N & Std. Deviation & Std. Error Mean \\
\hline \multirow{2}{*}{ Pair 1 } & Shipping Accident & 1633633300.0000 & 30 & 1085000877.606 & 1467552320.82308 \\
& Insurance expenditure on losss control and management. & 6449734181290.3220 & 30 & 8848993990966.45300 & 1589326238380.64580 \\
\hline
\end{tabular}

Source: Authors computation.

As indicated in the table, the mean shipping accident economic loss over the period covered in the study amounts to 1633633300.00 naira while mean insurance expenditure on shipping accident loss management is 6449734181290.32 naira. The difference of the two means is 5342691905064.5naira in favour of insurance expenditure on shipping accidents loss management. The result shows that more has been expended in management of shipping accidents than average economic losses over the period.

\subsection{Test of Hypotheses}

Table 5. Hypothesis $H_{o 1}$ : T-statistic on significance of impact of shipping accidents economic loss on marine transport GDP.

\begin{tabular}{lllll}
\hline Hypothesis & t-score & t-critical & p-value & Sig.(p < 0.05) \\
\hline $\mathrm{H}_{\mathrm{o} 1}$ & 2.48 & 1.701 & 0.020 & Decision \\
\hline
\end{tabular}

Source: Authors own computation based on data collected.

The result shows that shipping accidents economic loss has significant impact on the output of the marine transport subsector. Thus we reject the null hypothesis that shipping accidents economic loss has no significant impact on marine transport subsector output to accept the alternate.

Table 6. Hypothesis $H_{o 2}$; T-statistic on significance of impact of economic loss of off shore O\&G accidents on marine transport subsector output.

\begin{tabular}{|c|c|c|c|c|c|}
\hline Hypothesis & t-score & t-critical & p-value & Sig. $(p<0.05)$ & Decision \\
\hline $\mathrm{H}_{\mathrm{o} 2}$ & 2.50 & 1.701 & 0.020 & Yes & Reject $\mathrm{H}_{\mathrm{o} 2}$ \\
\hline
\end{tabular}

Source: Authors own computation based on research data.

The result shows a rejection of null hypothesis $\mathrm{H}_{\mathrm{o} 2}$ and the acceptance of the alternate that economic loss of offshore O\&G accidents has significant impact marine transport subsector output.

Table 7. Hypothesis $H_{o 3}$ : T-statistic on significance of impact of marine oil spill accidents economic loss on marine transport output.

\begin{tabular}{|c|c|c|c|c|c|}
\hline Hypothesis & t-score & t-critical & p-value & Sig. $(p<0.05)$ & Decision \\
\hline $\mathrm{H}_{\mathrm{o} 3}$ & 0.912 & 1.701 & 0.370 & No & Accept $\mathrm{H}_{03}$ \\
\hline
\end{tabular}

Source: Authors own computation based on research data.

The analysis shows the acceptance of null hypothesis $\mathrm{H}_{03}$. Thus, marine oil spill accidents economic loss has no significant effects on the output of the marine transport subsector.

Table 8. Hypothesis $H_{04}$ : T-statistic on difference between shipping accidents economic loss and insurance expenditure on shipping accidents loss control.

\begin{tabular}{|c|c|c|c|c|c|}
\hline Hypothesis & t-score & t-critical & p-value & Sig. $(p<0.05)$ & Decision \\
\hline $\mathrm{H}_{\mathrm{o} 4}$ & 4.057 & 1.701 & 0.000 & Yes & Reject $\mathrm{H}_{04}$ \\
\hline
\end{tabular}

Source: Authors own computation based on research data.

The result reveals that there is a significant difference between shipping accidents loss and insurance expenditure on shipping accidents loss management and control. More insurance expenditure has been made than actual losses suffered over the period.

\section{Conclusion}

From the foregoing, the average aggregate marine accidents economic losses in the period covered in the study is 2,608,236,616.013 naira. Shipping accidents economic loss, and economic loss of offshore $\mathrm{O} \& \mathrm{G}$ drilling accidents shows significant impacts on the output $\left(\mathrm{GDP}_{\text {marine transport }}\right)$ of the marine transport sub-sector. However, marine oil spill economic loss failed to show any significant effects on the output of the subsector. Moreover, significant difference exists between shipping accidents economic loss and insurance expenditure on management of shipping accident losses. On the average, more financial cost has been expended on risk transfer as a loss control mechanism than 
actual losses suffered.

\section{Recommendation}

Based on the findings of the study, in order to optimize the economic losses imposed by accidents in the marine industry, safety management measures and loss control tools should be focused more on shipping accidents and offshore $O \& G$ drilling accidents which impact very significantly on the output of the subsector.

Moreover, since Nigeria as an International Maritime Organization (IMO) member country has over the years adopted and ratified majority of the IMO Convention instruments for Safety regulation, such as the safety of life at sea (SOLAS) 1974 as amended, standards of training certification and watch keeping (STCW) 1995 as amended, international regulations for the control of marine pollution from ships (MARPOL) 73/78, the load lines (LL) convention of 1966, the regulations for the control of vessel collision at sea (COLREGS) 1972, the international convention on maritime search and rescue (SARS) 1979 as amended, the international ship and port facility security (ISPS) code, Port States control (PSC) etc, diligent implementation of these safety instruments will help to minimize the high degree and increase in trend of marine-accident induced output losses in the subsector. This will subsequently impact on the high expenditure on marine insurance being made at present in managing marine accidents by ensuring lowered costs of insurance premium.

\section{References}

[1] Vouker Schellhammer (2014) Annual report on maritime casualty investigation. Federal bureau of maritime casualty investigation, ministry of transport and digital infrastructure, Germany.

[2] MAIB (2008) Annual Statistical Report of the marine Accident Investigation Boards. Available at: www.amem.at Retrieved on 22/10/2016.

[3] Nnadi, K. U. (2014) The Economics of market Contestabilityin Nigeria Coastal Shipping, Seminar Paper at the School of Management Technology, Federal University of Technology, Owerri.

[4] Nze, I. C. (2013) Analysis of the Fatality Rates of Boat and Ferry Accident on Inland Waterways in Nigeria, IOSR Journal of Business and ManagementVol.11(2): 17-20.

[5] UNCTAD (2014) Annual Statistical Report on Maritime Transport. A Publication of the United Nations Convention on Trade and Commerce.

[6] CBN (2013) Central Bank of Nigeria Statistical Bulletin, 2013 edition.

[7] NIA (2014) Insurance Digest, Annual Statistical Publication of the Nigeria Insurers Association, Lagos.

[8] NPA (2014) Nigerian Ports Authority Annual Statistical Bulletin, 2014 edition. Available at http/l
www.npa.org.ng/Retrieved on 23/12/2016.

[9] Nwokedi T. C., Okoroji L. I. and Onyemechi C. (2014) An Analysis for Reduction in Economic Loss from Damage Accident in use of Transport Modes: A Comparative Study, Journal of Economics and Sustainable Development Vol.5 (8): 182-189.

[10] IMO (1997): FSA Trial Application to High Speed Passenger Catamaran Vessel, London, International Maritime Organization: MSC68/14/2.

[11] Nwokoro I. A., Nwokedi, T. C., (2015) An Evaluation of the Economic and Financial Capacity of Indigenous Underwriting firms for Marine Risk and Investment Cover in Nigeria, International Journal of Research in Commerce, IT and Management Vol. 5(3):62-66.

[12] Eberhard Feess and Ulrich Hege (1999) The role of insurance in the Adjudication of multiparty accidents. International review of law and economics 19:69-85.

[13] RistoJ. and Kim, S. (2009) Safety performance indicators for Maritime Safety, Department of Applied Mechanics, Helsinki University of Technology.

[14] Ogwude, I. C. (1998) Valuation of Reduction in Traffic Accidents, The Trainer: Journal of the Institute of Transport and Logistics Zaria, June-September (1998): 18-27.

[15] Ando A. W., et al. (2007) Natural Resource Damage Assessment Methods and Cases, WMRC's Research Report Series. Available online at: http://www.wrurc.uiuc.edu/ Retrieved on July 6, 2014.

[16] Grey, D., \& Rob, F. (1997) The Economic Impacts of Accident on the Marine Industry, Prepared for the U.S. Coast Guard, Standards Evaluation and Development Division, Washington, D. C.

[17] Simo, Salminen (2012), Theories of Occupational Accident. Finish Institute of Occupational Health, Finland.

[18] OSHA (2013) Accident Investigation and Control. Available at: //.www.oshatrain.org.Retrieved 12/06/2016.

[19] Bijwaard G. and Knapp S. (2009) Analysis of ship life cycles - the impact of economic cycles and ship inspections. Marine policy volume 33: 350-369.

[20] Webster (1983) Webster online dictionary. Available at:www.webster.org. Retrieved 12/06/2016.

[21] Anyanwu, J. O. (2014) The Causes and Minimization of Maritime Disasters on Passenger Vessels, Global Journal of Researches in Engineering 14(2):1-13.

[22] Rosa E. A. (2013) The logical structure of the social amplication of risk framework (SARF): meta-theoretical foundation and policy implications. In N. Pidegeon, R.E. Kaspersen and P. Slovic (eds). The social amplification of risk. Cambridge University press, Cambridge.

[23] Trevisani, Daniele (2007) The Direction of change. Milan, Franco Angeli, ISBN: 9788846483775.

[24] ISO (2009) Risk Management: Principles and guidelines on implementation. International Standard organization. Document no: $31000-2009$.

[25] Pedro, A. C. and Guedes, S., (2008) Casual factors in accident of high-speed craft and conventional ocean-going vessels. Reliability engineering and system safety 93: 1292-1304. 
[26] Onwuegbudunam, D. E. (2013) An Analysis of Determinants of Accident Involving Marine Vessels in Nigeria's Waterways, Journal of Management Science and Engineering 7(3): 39-45.

[27] Gorkce, C. C., (2004) The impact of shipping accident on marine environment: study of Turkish seas. European scientific journal vol.10, (23) 1857-788.

[28] Akhatar M. J. (2014) Fatigue at sea- a Manning problem, Journal of Maritime Research XI (III): 27-42.America Army material command (1971) Fault Tree analysis as an aid to improved performance. US Army material command (AMC) safety digest, May 1971.

[29] Harilaos, et al (1998): An Analysis of Maritime Transportation Risk Factors, Paper Presentation at ISOPE Conference, Montreal, Canada.

[30] Adebiyi, K. A. (2008) Estimation of Air Traffic Accident Cost in Nigeria, Pacific Journal of Science and Technology 9(2): $420-425$.

[31] Young Sik Toon, Dong-Han Han and Wan Chul Yoon (2016) Application of Activity Theory to analysis of human-related accident: Method and case studies. Reliability Engineering and system safety Journal 150 (2016) 22-34.

[32] Ludwig, Benner Jr. (2012) Accident Investigations: A Case for New Perceptions and Methodologies. Available at: //www.ludwigbanner.org., Retrieved on 12/06/2016.

[33] Rasmusen J. and Svedung I. (2002) Graphic representation of accident scenarios: mapping system structure and the causation of accidents. Safety science Vol. 40(2002) 397 417.

[34] Heirich, H. (1959) Industrial Accident Prevention: A Scientific Approach ( $4^{\text {th }}$ edition). New York, McGraw Hill.

[35] Viner D. (1999) Accident Analysis and Risk Control. New Delhi, Derek Viner Pty Ltd.

[36] Jan Hovden, Eirik Albrechtsen and Ivonne Herrera Pork (2010) Is there a need for new theories, models and approaches to occupational accident prevention? Safety Science Journal Vol. 48 (2010) 950 - 956

[37] ABS (2014) Risk Assessment Applications for the Marine and Offshore Oil and Gas Industries. Houston, American Bureau of Shipping.

[38] Arben Mullai and Ulf Paulson (2011) A grounded Theory Model for analysis of Marine Accidents. Accident Analysis and Prevention Journal Vol. 43(2011) 1590-1603.

[39] Kin Hyungju, Haugen Stein and Utue I. Bouwer (2016) Assessment of accident theories for major accidents focusing on the MV SEWOL disaster: Similarities, differences and discussion for a combined approach. Safety Science Journal 82 (2016) $410-420$

[40] Ludwig, Benner Jr. (1979), Four Accident Investigation Games Simulations of the Accident Investigation Process. Oakton, VA, Lufred Industries Inc.

[41] Ludwig, Benner Jr. (1978) Accident Theory and their Implications for Research. Paper Presented at the Joint International Meeting of the American Association for Automotive Medicine and the International Association or Accident and Traffic Medicine, Ann Arbor, Michigan. July 10.
[42] Osiris A. and Valdez Banda (2015) A risk analysis of Winter navigation in finish sea areas. Accident Analysis and prevention Journal Vol.79 (2015) 100-116.

[43] Cortardan, J., (2009) The digital hand: How computers changed thew work America Industrial Loss Control Sector. Oxford University Press, New York.

[44] Hubbard, Douglas (2009) The failure of Risk Management: Why itis broken and how to fix it. New York, John Wiley and Sons.

[45] Coso (2004) Enterprise Risk Management integrated framework. Available at http//www.coso.org. Retrieved on 23/12/2016.

[46] Andrea, R., Lara, L. T., Sergi, C., and Joaquim, C., (2009) economic evaluation of damages originated by major accidents in port areas. Journal of loss prevention in the process industries.

[47] Irukwu J. O (2007) Extending the traditional frontiers of insurance. Journal of the life officers committee of the Nigeria insurance association Lagos vol 5 (2997) pg 66-73.

[48] Axel, H. (2014) Safety Assessment of New e-Navigation Systems, International Journal of e-Navigation and Maritime Economy 1(2014): 14-28.

[49] Wayne K. Talley (1999) Determinants of the property damage costs of tanker accidents. Transportation research part D 413426.

[50] Difford, P. (2011) Redressing the Balance: a common sense approach to causation. U.S.A, Accidental Books.

[51] Reason James (2001) Managing the Risks of Organizational Accidents. London, Hants Ashgate Publishing Limited.

[52] Ert, E \& Erev, I. (2008) Theregation of attractive giantess, Loss aversion and the Iemon avoidable heuristics. Journal of economic Psychology, 715-723.

[53] Thorndyke, R. L., (1951) The Human factor in Accident.US Air force School of Aviation Medicine, Project Report, Project No. 21-30-001.

[54] International Standard Organization (ISO, 2004) "White Paper on risk Governance: Toward an Integrated approach. ISO, Geneva.

[55] Haddon, W. Jr. (1968) The Changing Approach to the Epidemiology, prevention and Amelioration of Truama. The Transition to Approaches Etiologically Rather than Descriptively Based. Journal of Public Health Vol. 58(8) 7079 .

[56] Sajid Moly Uldin, Khurrun S. Mughal, Unier Farooq (2013) Impact of cost of Marine and general Insurance on International Trade and economic growth in Pakistan. World Applied Sciences Journal Vol. 28 (5) 659-671.

[57] Haddon W.(2003) Energy Damage and the Ten Counter measure Strategies. The Journal of Trauma, Vol. 13 (4) 142220 .

[58] Pennings, J. M \& Smiths, A. (2000) Assessing the Courstuct Validity of risk attitude. Management Science, 1337-1348.

[59] Flyvbjerg, Bent and Budzier, Alexander (2011) Why your Project may be Riskier than you Think. Harvard Business Review 89 (9): $601-603$. 
[60] Keeney, R. L., \& Raiffa, H. (1976) Decisions with multiple objectives: Preferences and Value tradeoffs. John Wiley \&Son. New York.

[61] Okon, J. E. (2012) Safety and Security Aspects of Maritime Transport, Uyo: Modern Business Press.
[62] Qingji, Zhou and Vinh, V. Thai (2016), Fuzzy and grey Theories in failure mode and effect analysis for tanker equipment failure prediction. Safety Science Journal 83 (2016) pg:74- 79. 